International Journal of Instruction e-ISSN: 1308-1470 • www.e-iji.net
July $2018 \bullet$ Vol.11, No.3

p-ISSN: 1694-609X

pp. 265-276

Received: 17/10/2017

Revision: 07/03/2018

Accepted: 11/03/2018

\title{
Relationship between 21st Century Skills, Speaking and Writing Skills: A Structural Equation Modelling Approach
}

\author{
Khalil Motallebzadeh
}

English Department, Torbat-e-Heydarieh Branch, Islamic Azad University, Torbat-eHeydarieh, Iran, k.motalleb@iautorbat.ac.ir,kmotallebz@gmail.com

\section{Fatemeh Ahmadi}

English Department, Torbat-e-Heydarieh Branch, Islamic Azad University, Torbat-eHeydarieh, Iran, fateme.ahmadi51@yahoo.com

\section{Mansooreh Hosseinnia}

English Department, Torbat-e-Heydarieh Branch, Islamic Azad University, Torbat-eHeydarieh, Iran, mansoorehhossinnia@yahoo.com

Teaching and learning in the 21st century is dealt with challenges and novelties. This study was conducted to investigate the relationship between 21 st century skills, EFL learners' speaking and writing skills. The participants comprised 122 EFL learners from three private language institutes of Mashhad. Their selection was based on convenience sampling and the participation was entirely voluntary. The instruments used in this study consisted of 21 st century skills questionnaire developed by Ashraf, Motallebzadeh, and Arabshahi (2014). Pearson's correlation coefficient, independent sample t-test, and structural equation modeling (SEM) were run to analyze the relationships among the 21 st century skills components. Results of Structural Equation Modeling indicated that 21st century skills had a significant relationship with students writing and speaking. The interrelationship among five sub-constructs of 21st Century Skills Questionnaire (critical thinking and problem solving, communication and collaboration, interpersonal skills, leadership, and technology literacy) were analyzed on speaking and writing scores. Among five sub-constructs of 21 st century skills questionnaire communication and collaboration had the highest correlation with foreign language speaking score and technology literacy had the highest correlation with foreign language writing score.

Keywords: 21st century skills, speaking, writing, teaching, EFL

\section{INTRODUCTION}

Today's classrooms are different from the ones we have in our memories. The world is being changed. Today's students have been changed. They seek some other kind of

Citation: Motallebzadeh, K, Ahmadi, F., \& Hosseinnia, M. (2018). Relationship between 21st Century Skills, Speaking and Writing Skills: A Structural Equation Modelling Approach. International Journal of Instruction, 11(3), 265-276. https://doi.org/10.12973/iji.2018.11319a 
relationships with their teacher, classmates and instruction materials. They learn in different ways. They aren't strange creatures. They belong to their own world and they should be taught for their own age by their own methods. They are "no longer to be seen as a passive receptacle for knowledge, but instead as an active participant in the construction of knowledge" (Nissim et al. 2016, p.29). Students today "will graduate into a world where the demands of our professional, personal and public lives grow more complicated every year" ("Partnership for 21st century learning", para.2). Cator (2010, as cited in education week) argues that students today should evolve especial skills for being successful in a changing, interdependent, and complicated universe. Today, teaching must satisfy the requirements of a future determined by continual novelty and development (Pearson, 2015). "Teaching and learning in the 21st century is filled with challenge and opportunity, especially when teaching students for whom English is a new language" (ibid, p. 5). Nissim et al. (2016) asserts that the 21st century learning setting might be "a process-supporting system" that establishes a context in which learners learn more effective.

Speaking and writing are two of the four main second language skills. They are productive skills. Introducing oneself adequately and accurately or speaking fluently while communicating with native or knowledgeable speakers of a second or foreign language is the final aim of EFL learners and instructors in language teaching (Khademi, 2014). So, second or foreign language learning investigators have dealt with researching, examining, and evaluating spoken skill and proficiency (Hagen, 1990; Lantolf \& Frawley, 1985; 1988; 1992; Kenyon \& Malabonga, 2001; Liskin- Gasparro, 1984; Norris, 2001; Omaggio, 1983). Language instructors have tryed to promote teaching strategies and instructional exercises that develop L2 oral proficiency. Written skill is the most difficult skill for L2 learners. Because of the important role of writing skill on the process of second language acquisition, Chastain, (1980) asserts that the approaches and methods of teaching should be changed in second or foreign language classrooms.

Ashraf, Motallebzadeh and Arabshahi in an attempt designed and validated a questionnaire that could be used to evaluate EFL students in an EFL context in the 21st century skills. This questionnaire can help researchers to examine these skills in the classroom and to discover the relationship between these skills and some aspects of social, economic or psychological fields of study. So, according to the purpose of this study, this questionnaire will be used as one of the instruments. Thus, regarding the importance of 21st century skills in today's students' lives, this study aims to examine the effect of $21^{\text {st }}$ century skills on Iranian EFL learner's speaking and writing skills. The aim of this study is also increase the awareness of EFL teachers of the $21^{\text {st }}$ century skills, their importance, and their various exercises to transmit these skills to the students. Also, this study will notify teachers how to profit from the application of skills in their speaking and writing teaching process. Fahady and Motallebzadeh (2014) examined the effect of $21^{\text {st }}$ century skills on Iranian EFL learner's reading comprehension skill. But no study no study explored the effect of $21^{\text {st }}$ century skills on Iranian EFL learner's speaking and writing skills. Therefore, because of scarcity of studies in this field, this study aimed to engage in this important issue from the learners' point of view. Hence, this research gap exists. 


\section{Research Question}

In as much as the purposes of the study are to examine the relationship between $21 \mathrm{st}$ century skills, speaking and writing skills, this study addresses the following questions:

Q1: Is there any significant relationship between $21^{\text {st }}$ century skills and Iranian EFL learners' writing skill?

Q1: Is there any significant relationship between $21^{\text {st }}$ century skills and Iranian EFL learners' speaking skill?

\section{LITERATURE REVIEW}

Rich (2010, as cited in education week) defines 21 st-century skills as "certain core competencies such as collaboration, digital literacy, critical thinking, and problemsolving that advocates believe schools need to teach to help students thrive in today's world". 21st-century skills are the vital SS 21st-century skills that should be expanded into instructional organization, such as :1) "learning and innovation skills" 2) "information, media and technology skills"; and 3) "life and career skills" (Farisi, 2016). Quieng et al. (2015) argued that essence of $21^{\text {st }}$ century skills is equipping the individuals in future to confront the problems of real life positions to maintain the advancement of the world and convert it an improved situation to be alive. They also added that the purpose of educating and acquiring in the 21st century is to make students competent in "content knowledge, specific abilities, literacy, numeracy, and technology uses" (p.72). According to Pearson (2013) 21st century skills come into three categories: learning and innovation skills, information, media, and technology skills, as well as life and career skills.

$21^{\text {st }}$ centuries skills are one of the most important issues arisen from educators' concern about teaching youth. The Partnership for $21^{\text {st }}$ Century Skills (www.21stcenturyskills.com) has also developed a framework for $21^{\text {st }}$ century learning introducing the skills that students need to thrive in today's global economy. The framework developed by P12 is based on a solid foundation of content knowledge, and supported by specific skill, expertise, and literacies necessary for success in personal and professional domains. According to Partnership, every student must be a critical thinker, a problem solver, an innovator, an effective communicator, a self-directed learner, information and media literate, globally aware and civically engaged, and also financially and economically literate.

There are some themes in the instructional activities including global awareness, financial, economic, business, official literacy, civil literacy, health literacy and environmental literacy (Trilling \& Fadel, 2009).

Andrade (2016) in his study determined curricular components for learner achievement, just as the flipped classroom, course redesign, and high impact practices, and links these to self-regulated learning to increase learner responsibility for the achievement of desired higher education outcomes as 21 st century skills. Farisi (2016) investigated and explained academics evolution toward a commitment and further developments in research; 21st-century skills map for the SS; and the implications for developing teachers' competences and teachers' education curriculum. Suto (2013) in his study has cited some practical methods of how to develop the 21st century skills including: 
continue with long-standing methods of teaching 21 st century skills, develop curricula covering 21 st century skills explicitly, adopt a skills-centered pedagogy in schools and colleges, nurture 21 st century skills through extra-curricular activities, cultivate $21 \mathrm{st}$ century skills through independent research projects, and develop 21 st century skills in the workplace (p. 18).

In another study, Quieng et al. (2015) distinguished the recognized range of "integration of $21^{\text {st }}$ century-based soft skills in the cognitive-laden dentistry curriculum", and investigated the recognized "21stcentury-based soft skills of the student participants to serve as baseline data for future research". In their study, they conformed the special result areas of soft skills used in the study of Wilson-Ahlstrom, Yohalem, DuBois, and $\mathrm{Ji}$ (2011), such as "communication, relationships and collaboration, critical thinking and decision making, and initiative and self-direction". They found that Communication, and relationship and collaboration skills will be vital elements to provoke learners. Kivunja (2014) in his article, adapted the work of Kivunja (Kivunja, 2014a and 2014b) and expanded an awareness of the new learning paradigm by arguing its Career and Life Skills (CLS) domain. In a research study, Pishghadam and Mehr in 2011 with aim of examining the relationship between learner creativity and performance in written narrative tasks in the context of Iranian EFL students found a significant relationship between learners' performance in written narrative tasks and their total creativity and also with some sub constructs of creativity: fluency, originality and flexibility. Chen and Zhou (2010) investigated the ways of improving the creative writing strategies of young Chinese writers by using graphical representations to stimulate and help the development of writing skills. They found that when Chinese children faced those Chinese characters they were not able to write, they used creative writing skills to communicate. Artamonova (2002) carried out a research study to see whether a collaborative model affect the development of students' academic skills in the process of learning foreign language and English in particular. The results revealed that in order to be successful in a chosen specialty, it is necessary for students to acquire both academic and collaborative skills. Fahiminia, Jahandar, and Khodabandehlou (2013) explored the role of collaboration in influencing Iranian learner's beliefs about EFL vocabulary instruction. The results of their study indicated that collaborative learning had a significant effect on EFL learners' belief about learning vocabulary and also on their vocabulary learning. Mahyuddin et al. (2004)'s research study revealed that language learners with critical thinking abilities are capable of thinking critically and creatively in order to achieve the goals of the curriculum; capable of making decisions and solving problems; capable of using their thinking skills, and understanding language or its content; capable of treating thinking skills as lifelong learning; and finally, intellectually, physically, emotionally and spiritually well-balanced. Ketabi, Zabihi, Ghadiri (2012) investigated ELT teachers' understanding of critical thinking really means and whether it should be incorporated into the ELT curriculum. The results of their study revealed that EFL teachers tended to express strong support for the incorporation of critical thinking into the ELT curriculum. Kashefian (2002)'s investigation of the English learners' beliefs towards autonomous language learning revealed that factors such as 
learner independence, dependence on teacher, learner confidence, attitudes towards language learning, and self-assessment exist in Iranian educational setting.

Regarding the effectiveness of other approaches on teaching speaking and writing, lino et al. (2016) examined "the effects of using Video conferencing (VC) as a tool for foreign language instructions in a semester long research study". Their results revealed that "using VC with tasks in a blended manner with classroom instruction develops balanced L2 competence and performance". Farhady and Motallebzadeh (2014) in his study examined the effect of 21 st century skills on reading comprehension. His results have shown that 21 st century skills have a positive effect on reading comprehension. Therefore, instead of listening and speaking, 21st century skills also have a significant effect on the reading comprehension. Maley \& peachy (2010) in an attempt proposed some creative writing activities can be used in ELT classrooms. Golpour (2014) examined "the relationship between critical thinking levels of Iranian EFL learners and their performance on different modes of writing". He revealed that "the high critical thinkers' writing was better in both modes of writing compared to the low critical thinkers". Finally, Ashraf et al. (2016) developed and validated a self-reported questionnaire with the aim of evaluating ELT community's performance in the $21 \mathrm{st}$ century skills. They argued that "the 21 st CSQ is then a valid and reliable questionnaire which can be used for several studies in the area of the new world skills needed to live and work" (p.15). For us, as English teachers, how can we use 21st century skills in our classroom and which effect it will have on their language skills? This study was conducted in order to look into integrating 21st century skills into teaching English in Iranian context and investigate its effect on speaking and listening skills.

\section{METHOD}

\section{Participants}

To collect the required data, a total number of 222 EFL learners (168 female, 54 male) were chosen to participated in this study from three private language institutes of Mashhad, Khorasan-e-Razavi, Iran. Their selection was based on convenience sampling technique and the participation was entirely voluntary. This convenience sampling strategy is favored, because random sampling is not practical for most classroom studies. They were equal number of male and female and their ages ranged between 15 and 40 (mean=24.35, SD=4.24). All of them were intermediate and upper-intermediate learners of English.

\section{Data Collection Instruments}

Two instruments were used in this study. The first one is the questionnaire developed by Ashraf, Motallebzadeh, and Arabshahi (2014) was used. This questionnaire was comprised of two sections. The first part raises six major questions requiring short answers dealing with the participants' gender, age, school name, English language proficiency level, language learning experience, and their level of education. The second part of the $21^{\text {st }}$ CSAQ consisted of 50 items. The questionnaire comprised 50 items that were scored according to Likert-type scale of five points ranging from (1) "Not at all/Never" to (5) "Entirely/Always". The internal consistency of the whole questionnaire was examined with the Cronbach Alpha reliability estimate. The Cronbach Alpha estimated the reliability of the whole test as 0.82 . 
Table 1

The Descriptive Statistics of $21^{\text {st }}$ CSAQ

\begin{tabular}{llll}
\hline$\neq$ Areas & Statements & $\neq$ of Items & Percentage \\
\hline Critical thinking & $1-2-3-4-5-6-31-32-33$ & 9 & $18 \%$ \\
\hline Interpersonal skills & $7-8-39-40$ & 4 & $8 \%$ \\
\hline Communication & $9-10-11-12-13-14-15-16-26-27-28$ & 11 & $22 \%$ \\
\hline Technology literacy & $29-30-34-35-36-38-44-45-46-47-48-49-50$ & 13 & $26 \%$ \\
\hline Leadership & $17-18-19-20-21-37-41-42-43$ & 9 & $20 \%$ \\
\hline
\end{tabular}

The second one is EFL learners' IELTS speaking and writing score. IELTS test, a high stakes selection test, has been recognized worldwide as a reliable measure of candidates' English language proficiency to study at a tertiary institution. IELTS is made up of four different subtests: Listening, Reading, Writing and Speaking. The scores the students had received on the actual IELTS test was reported by the students. IELTS test is a highly valid English proficiency test administered by Cambridge University all around the world.

\section{Procedure}

After getting permission from the supervisors and teachers of the English institutions, the researchers distributed the questionnaire among English language learners. Learners completed the scale at their specified time frame. Also, their actual IELTS scores on speaking and writing were reported by the students. After gathering the scale, the data were analyzed by the SEM approach of Amos software.

\section{Data Analysis}

To find out whether $21^{\text {st }}$ century skills teaching would have any effect on Iranian EFL learner's speaking and writing, quantitative data collection and analysis were utilized. In this way, SPSS software was applied to carry out various data analyses of this study such as reliability, and correlation. To check the reliability of all the data collected via completion of the questionnaires of $21^{\text {st }}$ century skills awareness questionnaire, Cronbach's Alpha was checked. In order to have a better understanding of the role of five sub-constructs of 21st Century Skills Questionnaire on foreign language speaking and writing scores, Structural Equation Modeling (SEM) of Amos software was used.

\section{FINDINGS}

Descriptive statistics and correlations between five sub-constructs of $21^{\text {st }}$ Century Skills Questionnaire (Critical thinking and problem solving, Communication and collaboration, Interpersonal skills, Leadership, and Technology literacy), speaking and writing scores are given in Table 2. As can be seen in Table 2, among five subconstructs of $21^{\text {st }}$ Century Skills Questionnaire Communication and collaboration had the highest correlation with foreign language speaking score $(r=.71, p=.00)$ Technology literacy had the highest correlation with foreign language writing score $(r=.68, p=.00)$. In addition, among five sub-constructs of $21^{\text {st }}$ Century Skills Questionnaire Critical thinking had the lowest correlation with foreign language speaking score $(r=.34, p=.00)$ Critical thinking had the lowest correlation with foreign language writing score $(\mathrm{r}=.29$, $\mathrm{p}=.00)$. 
Table 2

Descriptive statistics and correlations

\begin{tabular}{llccccccc}
\hline & Mean (SD) & 1 & 2 & 3 & 4 & 5 & 6 & 7 \\
\hline 1. Critical thinking & $20.17(7.02)$ & 1.00 & & & & & & \\
2. Communication & $16.24(3.15)$ & $.29^{* *}$ & 1.00 & & & & & \\
3. Interpersonal skills & $7.20(1.21)$ & $.11^{*}$ & $.67^{* *}$ & 1.00 & & & & \\
4. Leadership & $6.43(1.77)$ & $.19^{* *}$ & $.53^{* *}$ & $.52^{* *}$ & 1.00 & & & \\
5. Technology literacy & $19.97(5.29)$ & $.16^{*}$ & $.39^{* *}$ & $.43^{* *}$ & $.29^{* *}$ & 1.00 & & \\
6.Speaking score & $7.75(1.19)$ & $.34^{* *}$ & $.71^{* *}$ & $.56^{* *}$ & $.53^{* *}$ & $.38^{* *}$ & 1.00 & \\
7.Wrting score & $5.97(2.09)$ & $.29^{* *}$ & $.47^{* *}$ & $.49^{* *}$ & $.40^{* *}$ & $.68^{* *}$ & $.54^{* *}$ & 1.00 \\
\hline
\end{tabular}

**Correlation is significant at the level of 0.01

*Correlation is significant at the level of 0.05

In order to have a better understanding of the role of five sub-constructs of 21 st Century Skills Questionnaire on foreign language speaking and writing scores, Structural Equation Modeling (SEM) was used. Figure 2 indicates the interrelationship among five sub-constructs of 21st Century Skills Questionnaire on foreign language speaking and writing scores. A number of fit indices were examined to evaluate the model fit. As the model shows, among all the fit indices, CFI (.95), GFI (.90), NFI (.86), the chi-square/df ratio (2.932), RMSEA (.089), NFI and RMSEA did not lie within the acceptable fit thresholds based on Schreiber, Nora, Stage, Barlow, and King (2006). Hence, the model does not fit the data perfectly.

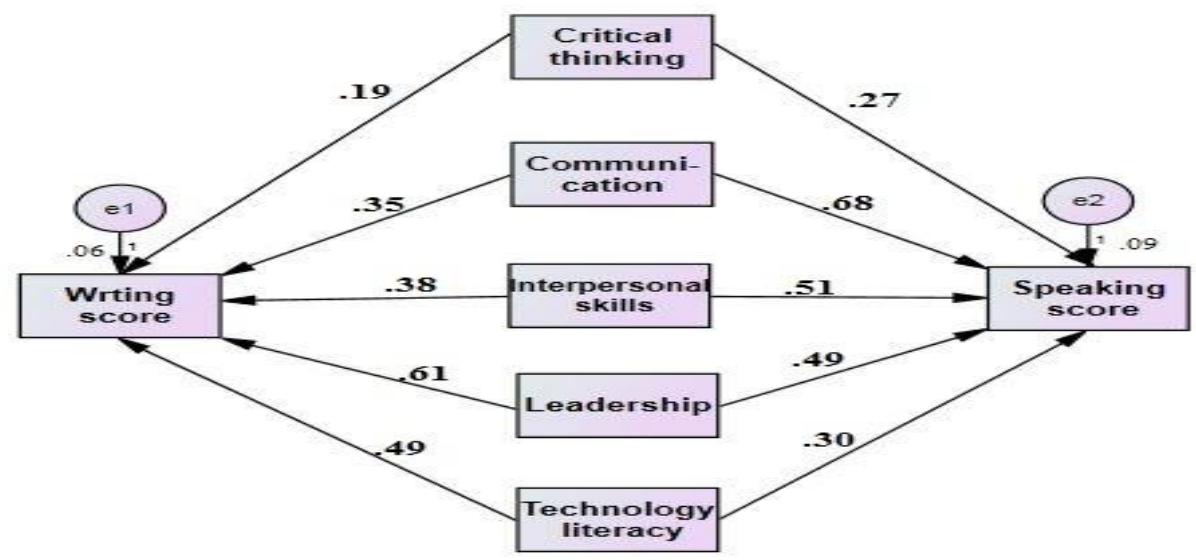

Figure 2 Interrelationship among five sub-constructs of 21 st Century Skills Questionnaire, foreign language speaking and writing scores

As indicated in Figure 2, all five independent variables positively and significantly predict students' foreign language writing scores: Critical thinking $(B=.19, p<05)$, Communication $(B=.35, p<05)$, interpersonal skills $(B=.38, p<05)$, leadership $(B=.61$, $p<05)$, and technology $(B=.49, p<05)$. In addition, all five independent variables positively and significantly predict students' foreign language speaking scores: Critical thinking $(B=.27, p<05)$, Communication $(B=.68, p<05)$, interpersonal skills $(B=.51$, $p<05)$, leadership $(B=.49, p<05)$, and technology $(B=.30, p<05)$. 


\section{DISCUSSION AND CONCLUSION}

The objective of the present study was to examine the relationship between 21st century skills, speaking and writing skills. For this purpose, two questions were posited: (1) "Is there any significant relationship between $21^{\text {st }}$ century skills and Iranian EFL learners' writing skill?" (2) "Is there any significant relationship between $21^{\text {st }}$ century skills and Iranian EFL learners' speaking skill?" The research questions were addressed by examining the proposed model with SEM. According to the results, 21st century skills had a significant relationship with students writing and speaking. The interrelationship among five sub-constructs of $21^{\text {st }}$ Century Skills Questionnaire (Critical thinking and problem solving, Communication and collaboration, Interpersonal skills, Leadership, and Technology literacy) were analyzed on speaking and writing scores. Among five sub-constructs of $21^{\text {st }}$ Century Skills Questionnaire Communication and collaboration had the highest correlation with foreign language speaking score and Technology literacy had the highest correlation with foreign language writing score. Therefore, all five independent variables positively and significantly predict students' foreign language speaking and writing scores.

This study has some implications. Considering using of $21^{\text {st }}$ century skills in EFL classes will improve learning mechanism by shaping appealing and fascinating environments, it is clear that teachers should create better circumstances for increasing the broad application of it in any stage of language acquisition process. So, the first step should be increasing awareness of teachers of the $21^{\text {st }}$ century skills, their importance, and their various exercises. Knowledgeable teachers will best transmit these skills to the students. Thus, teachers can not only profit from the application of skills in their teaching process and increase their information about teaching by means of "new technologies or the other skill areas like problem- solving, creativity, cooperation, critical thinking, etc., they can get proficiency and mastery on preparing and revising the best way to teach these kinds of skills" (Arabshahi et al. 2015, p.76). There are numerous benefits towards implementing a collaborative context for learning. Sharan (1980) states that integration of collaborative structures into pedagogical approaches through which the individual learner transitions into some collaborative learning environment experiences significant improvements in leaning outcomes. There exists a significant positive relationship between learners' involvement in collaborative leaning environments and their critical thinking skills (Gokhale, 2005), and a sense of shared constructions of meaning. Moreover, Bruffee (1984) claims that such learning contexts enable the students to transfer the social skills promoted in the learning group to meaningful participation in the social interactions. Nunan (1992) also refer to the one of the critical aspects of language learning process in which the students are allowed to share and listen to other learners' stories and opinions. According to him this feature can be made possible by employing collaborative learning models, especially in the ESL context, allowing for students voices to be heard. Bandura (1977) suggests that low achieving students can develop higher level of thinking skills more readily in collaborative groups due to modeling. Also, Kewley (1998) states that peer collaboration encourages maximum student participation at the ideal level, resulting in more flexible thinking, multiple solutions, and a clearer understanding of the steps leading up to those solutions. 
This very fact that creativity and innovation are very high on the list of $21^{\text {st }}$ century skills, is not surprising given the fact that $21^{\text {st }}$ century demands to continuously innovate new services, better processes, and improved products for the world's global economy. Erstad (2008) state that creative practices challenge the traditional relationship between teachers and students in providing information and content for learning, and the role of school book. Such creative practices encompass Web 2.0 technology enabling users to produce and share content in new ways like user generated content creation and remixing (Lessig, 2008).

Aytan (2016) in his study, tried to distinguish the influence of a listening education program on the listening conducts of prospective Turkish instructors. According to his results, the Listening Education program has produced an understanding in prospective Turkish instructors of listening types and has developed their levels of sensitivity in applying body language. A study has been done about 21 st century skills and the workplace through which 1,014 interviews with members of the Gallup Panel aged 1835 years were implemented (Gallup, 2013). The result emphasized to this matter that most of the skills they utilized at their job were developed out of the classroom. In another study, Motallebzadeh and Kafi (2015) examined "the possible significant effects of project-based instruction on the improvement of Iranian intermediate EFL learners' awareness of 21 st century skills". Their finding revealed that students in the experimental group could perform much better than learners in the control group after the treatment on the post-test. Therefore, they found significant effects of project-based instruction on the improvement of Iranian intermediate EFL learners' awareness of $21 \mathrm{st}$ century skills. In another study, Pishghadam (2008) has shown that literary discussion in a foreign language learning class can improve the critical thinking abilities of language learners. Therefore, the results of different studies have shown the significant effect of 21 st century skills on language skills. So, the result of this study confirms the findings of those studies.

\section{REFERENCES}

Andrade, M. S. (2016). Curricular elements for learner success $21^{\text {st }}$ century skills. Journal of Education and Training Studies, 4(8), 143-149.

Arabshahi, M., Ashraf, H., \& Motallebzadeh, K. H. (2015). On the relationship between the Iranian intermediate EFL learners' $21^{\text {st }}$ century skills awareness and their level of anxiety in EFL classes (Unpublished doctoral thesis), Islamic Azad University of Torbat-e Heydarieh, Iran.

Artamonova, A. (2002). The role of collaboration in the development of students' motivation in the process of learning English at tertiary level. Studies about Languages, 2, 82-86.

Ashraf, H., Motallebzadeh, K. H., \& Arabshahi, M. (2015). On the design, validation and reliability of the 21st century skills questionnaire in an EFL context. Modern Journal of Language Teaching Methods, 6 (3), 1-19. 
Aytan, T. (2016). The effect of a listening education course on the listening behaviors of prospective Turkish teachers. International Journal of Higher Education, 5(2), 254-262.

Bandura, A. (1977). Social learning theory. Englewood Cliffs, NJ: Prentice Hall.

Bruffee, K. A. (1984). Collaborative learning: higher education. Interdependence and the Authority of Knowledge. Baltimore, MD: John Hopkins University Press.

Chastain, K. (1980). Native speaker reaction to instructor-identified student second-language errors. The Modern Language Journal, 64(2), 210-215. http://dx.doi.org/10.1111/j.1540-4781.1980.tb05187.x

Erstad, O. (2008). Trajectories of remixing- digital literacies, media production and schooling, In C. Lankshear \& M. Khobel (Eds.). Digital literacies: Concepts, policies and practices. New York: Peter Lang. pp. 177-202.

Fahiminia, R., Jahandar, S., \& Khodebandehlou, M. (2013). The impact of collaborative learning on Iranian EFL learner's beliefs about vocabulary learning. Indian Journal of Fundamental and Applied Life Sciences, 3(2), 150-163.

Farhady, H. \& Motallebzadeh, K. H. (2014). The effects of 21st century skills awareness on reading comprehension: A quantitative and qualitative study in an EFL context. (Unpublished doctoral thesis), Islamic Azad University of Torbat-e Heydarieh, Iran.

Farisi, M. I. (2016). Developing the 21st-century social studies skills through technology integration. Turkish Online Journal of Distance Education,17(1),16-30.

Gallup. (2013). 21st century skills and the workplace, 1-19.

Gokhale, A. A. (2005). Collaborative learning enhances critical thinking. Journal of Technology Education, 7(1), 22-30.

Golpour, F. (2014). Critical thinking and EFL learners' performance on different writing modes. Journal of Pan-Pacific Association of Applied Linguistics, 18(1), 103-119.

Hagen, L. K. (1990). Logic, linguistics, and proficiency testing. ADFL Bulletin, 21(2), 46-51.

How do you define 21st-century learning? Education week. 4(1), 32-35. Retrieved April 16, 2017, from http://www.edweek.org/tsb/articles/2010/10/12/01 panel.h04.html

Iino, A., Yabuta, Y., \& Nakamura, Y. (2016). Effects of task-based videoconferencing on speaking performance and overall proficiency. In S. Papadima-Sophocleous, L. Bradley \& S. Thouësny (Eds), CALL communities and culture - short papers from EUROCALL 2016 (pp. 196-200). Research-publishing.net. https://doi.org/10.14705/rpnet.2016.eurocall2016.561

Kashefian Naini, S. (2002). An investigation into college EFL learners' beliefs demonstrating their predispositions towards learner autonomy. Masteral Thesis.Shiraz University, Shiraz, Iran.

Ketabi, S., Zabihi, R., \& Ghadiri, M. (2012). Critical thinking across the ELT curriculum: A mixed methods approach to analyzing L2 teachers' attitudes towards 
critical thinking instruction. International Journal of Research Studies in Education, 2(3), 15-24.

Chen, S., \& Zhou J. (2010). Creative writing strategies of young children: Evidence from a study of Chinese emergent writing. Thinking Skills and Creativity, 6, 67-87.

Khademi, M. (2014). The effect of chatting on the speaking of Iranian EFL language learners. International Journal of Language Learning and Applied Linguistics World, 6(1), 19-29.

Kenyon, D. M., \& Malabonga, V. (2001). Comparing examinee attitudes toward computer-assisted and other oral proficiency assessments. Language Learning \& Technology, 5(2), 60-83. Retrieved May 20,2005, from http://1lt.msu.edu/vol5num2/kenyon/

Kewley, L. (1988). Peer collaboration versus teacher-directed instruction: How two methodologies engage students in the learning process? Journal of Research in Childhood Education, 13(1), 27-32.

Kivunja, C. (2014a). Do you want your students to be job-ready with 21 st century skills? Change pedagogies: A paradigm shift From Vygotskyian social constructivism to critical thinking, problem solving and Siemens' digital connectivism. International Journal of Higher Education, 3(3), 81 - 91. Retrieved April 16, 2017, from http://dx.doi.org/10.5430/ijhe.v3n3p81

Kivunja, C. (2014b). Innovative pedagogies in higher education to become effective teachers of 21stcentury skills: Unpacking the learning and innovations skills domain of the new learning paradigm. International Journal of Higher Education, 3(4), 37 - 48. Retrieved April 16, 2017, from http://dx.doi.org/10.5430/ijhe.v3n4p37

Kivunja, CH. (2014). Teaching students to learn and to work well with $21^{\text {st }}$ century skills: Unpacking the career and life skills domain of the new learning paradigm. International Journal of Higher Education, 4(1), 1-11.

Lantolf, J. P., \& Frawley, W. (1985). Oral proficiency testing: A critical analysis. Modern Language Journal, 69(4), 337-345.

Lantolf, J. P., \& Frawley, W. (1988). Proficiency: Understanding the construct. Studies in Second Language Acquisition, 10(2), 181-195.

Lantolf, J. P., \& Frawley, W. (1992). Rejecting the OPI--again: A response to Hagen. ADFL Bulletin,23(2), 34-37.

Lessig, L. (2008). Making art and commerce thrive in the hybrid economy. New York: The Penguin Press.

Liskin-Gasparro, J. E. (1984). The ACTFL proficiency guidelines: Gateway to testing and curriculum. Foreign Language Annals, 17(5), 475-489.

Mahyuddin, R., Lope Pihie, Z. A., Elias, H., \& Konting, M. M. (2004). The importance of thinking skills in the school curriculum. Kajin Malaysia, JID, 22(2), 23-33. 
Maley, A., \& Peachey, N. (2010). Creativity in the language classroom. British Council 2015. Open Lean Works, Tess India. Retrieved May 5, 2016, from http://www.open.edu/openlearnworks/mod/oucontent/view.php?id=81160

Motallebzadeh, KH. \& Kafi, Z. (2015). Place-based education: Does it improve 21st century skills? International Journal of Applied Linguistics \& English Literature, 4(1), 89-94.

Nissim, Y., Weissblueth, E., Scott-Webber, L. \& Amar, SH. (2016). The effect of a stimulating learning environment on pre-service teachers' motivation and 21 st century skills. Journal of Education and Learning, 5(3), 29-39.

Norris, J. M., \& Ortega, L. (2003). Defining and measuring SLA. In C. Doughty \& M. H. Long (Eds.), Handbook of second language acquisition (pp. 717-761). Malden, MA: Blackwell.

Nunan, D. (1992). Collaborative language teaching. New York: Cambridge University Press.

Omaggio, A. C. (1983). Methodology in transition: The new focus on proficiency. Modern Language Journal, 67(4), 330-341.

Partnership for 21st century learning (2016). Retrieved April 16, 2017, from http://www.p21.org

Pearson. (2013). Empowering 21st century learners with results that matter. Pearson Education, Inc.

Pearson (2015). English Learners in 21st-century classrooms book. In how to teach in 21st century classrooms. Retrieved April 16, 2017, from ptgmedia.pearsoncmg.com/images/9780132685153/samplechapter/0132685159.pdf

Pishghadam, R. (2008). Afzayeshe tafakore enteghedi az tarighe mobahesye adabi. Journal of Literature, 48, 153-167.

Pishghadam, R., \& Javdan Mehr, F. (2011). Learner creativity and performance in written narrative tasks. World Journal of Education, 1(2), 115-125.

Sharan, S. (1980). Cooperative learning in small groups: Recent methods and effects on achievement, attitudes, and ethnic relations, Review of Educational Research, 50, 241-258.

Quieng, M.C., Lim, P.P, \& Lucas, M.R. (2015). 21 ${ }^{\text {st }}$ Century-based Soft Skills: Spotlight on non-cognitive Skills in a Cognitive-laden Dentistry Program. European Journal of Contemporary Education, 11(1), 72-81.

Suto, I. (2013). 21st century skills: Ancient, ubiquitous, enigmatic? Research Matters: A Cambridge Assessment Publication.

Wilson-Ahlstrom, A., Yohalem, N., DuBois, D., and Ji, P. (2011). From soft skills to hard data: measuring youth program outcomes. Washington, DC: The Forum for Youth Investment. 